\title{
PROGNOSTIC FACTORS IN STUTTERING
}

\author{
C. VAN RIPER \\ Western Michigan University, Kalamazoo, Michigan, U.S.A.
}

This paper seeks to review the basic information in the literature on stuttering which concerns itself with prognosis. We know that many beginning stutterers overcome the problem without professional speech therapy. We also know that cures and improvement have been reported by clinicians using a wide variety of approaches. It is also clear that many stutterers do not improve either through self-help or with the help of speech therapists. A survey of the meager research and the many statements by clinicians concerning prognostic data would seem to have some usefulness at this time, if only to demonstrate the importance of the problem.

Are there any Characteristics of the Normal Speech Shown by Stutterers which might have Prognostic Value? Wendahl and Cole ${ }^{49}$ have shown that the apparently normal speech of severe stutterers is characterized by irregularity in time and by more force and strain than that of normal speakers. These features could conceivably be used in prediction, and so too could measures of hesitation phenomena such as that of Mahl's ${ }^{31}$ non-ah ratios. Schilling and Goeler, ${ }^{39}$ Luchsinger and Dubois ${ }^{30}$ and many others have shown that the pitch range and inflections are more restricted in certain stutterers even when not stuttering and that these features usually indicate a severe problem. Hirschberg"1 says that a better prognosis is shown when the respiration is not affected. Froeschels ${ }^{17}$ mentions that the amount of air inhaled prior to speaking is a good measure of prognosis, that if it is normal rather than excessive in amount of intake, the prognosis is more favourable. Shearer ${ }^{12}$ states that his recovered stutterers attributed their improvement to speaking more slowly. Luper and Mulder $^{29}$ mention good eye-contact with the listener as a favourable sign and the presence of excessive tension as an unfavourable one. Robinson ${ }^{38}$ stresses the importance of speech consciousness and concern about communication as important factors in prognosis. These presumably must have their impact on the normal as well as the abnormal speech of stutterers. Other prognostic factors might be the sheer amount of daily talking time, the mean length of normal utterence, the average sound level of the stutterer's normal speech, and even the intelligibility. To our knowledge, no investigator has systematically investigated the incorporation of these leads in devising a prognostic measure. Surely the normal speech which the stutterer does possess might provide some important information?

Are There any Overt Features of the Stuttering Behaviour which Might Yield Prognostic Clues? There are many statements in the

Tydskrif van die Suid-Afrikaanse Logopediese Vereniging, Vol. 15, Nr. I: Des. 1968 
literature to the effect that when the stuttering behaviour is confined to simple and regular repetitions of syllables, if few in number, the prognosis is more favourable than when avoidance and struggle behaviours are present. Glasner and Rosenthal ${ }^{30}$ hold that the more complex the stuttering behaviour, the poorer the prognosis. Using three types of behaviours, excessive hesitation, excessive prolongation and excessive repetition, they found that $5 \mathbf{I} \%$ of their stutterers who had only one of these types of behaviours overcame their stuttering whereas only $35 \%$ of those having two or three of these patterns recovered. The openness or visibility of the stuttering behaviour has also been mentioned as indicating outcome. Freund $^{15}$, Douglass and Quarrington ${ }^{14}$ and others have stated that internalized or hidden stuttering constitutes a much more severe problem therapeutically than stuttering which is plainly overt, an opinion which has more recently been echoed by Danielson ${ }^{10}$ and Quarrington and Douglass. ${ }^{35}$ The variability of the stuttering symptoms has also been viewed as predictive, Schonharl ${ }^{\text {th }}$ stating that when the stuttering behaviours are highly consistent, the prognosis is more favourable than if they fluctuate in form.

The characteristic form of the stuttering behaviour has also generated many statements concerning prognosis. Froeschels ${ }^{18}$ mentions the läck of tonic blockings and also pseudo-tonic (closures without pressure) as indicating less deep-seated problems. He also maintains that if the release from blocking is gradual rather than sudden, the prognosis is better. Diamond's research ${ }^{11}$ showed that predominantly clonic stutterers had a better prognosis than predominantly tonic stutterers. Zerner ${ }^{i 3}$ tested the response of 102 stutterers to delayed auditory feedback. Those whose stuttering did not improve under D.A.F. he termed organic and did not treat. The remaining 77 became more fluent under D.A.F. and he classified these according to their major behaviours as tonic or clonic. The tonic group did not respond to therapy, but most of the clonic group made rapid progress.

Where stuttering seems to be associated with a strong cluttering component, the prognosis seems to be worse than when either disorder occurs alone (Weiss ${ }^{46}$ ), especially when the child is hyperactive or especially nervous. Kenyon ${ }^{20}$ has stressed the point that laryngeal blockings indicate a more severe problem than those where fixations occur in the lips and tongue alone, a conclusion which agrees with our own clinical experience. Multiple fixations also give us more concern than singles. We would also add that when vowels are excessively prolonged with a rise in pitch during the moment of stuttering, the clinical problem has always been very difficult.

In general, it appears that in children at least, the more frequent the moments of stuttering and the longer they last, the more likely it is that the prognosis is unfavourable. However, in adults, the converse may be true as Voelker ${ }^{47}$ and others have observed. Often the most grossly severe stutterers make the swiftest gains but this seems to depend upon the amount of avoidance behaviour and the overtness of the symptoms. 
A very severe overt stutterer has few word or phonemic fears since all sounds and words give him trouble and he has less to lose by confronting and working with his problem than those who have been able successfully to hide the disorder. In these stutterers, too, progress is more visible.

Some investigators have sought to investigate the roles of consistency, loci, and adaptation in determining prognosis. Lanyon ${ }^{27}$ found that when the stuttering consistently clustered about certain specific sounds and words, less improvement was shown than when more inconsistency in loci was present. This presumably reflects the intensity of word and phonemic fears. Quarringtor ${ }^{35}$ made the same point-the more consistentlyfeared words or sounds or word position fears shown by the stutterer, the poorer will be the prognosis. Johnson, Darley and Spriestersbach ${ }^{24}$ also stress the" consistency phenomenon, saying, in general, it may indicate how strongly his stuttering responses are associated with the stimuli or cues to which they have presumably been conditioned. Lanyon ${ }^{27}$ investigated the relationship between initial frequencies of stutterings and also adaptation rate in repeated readings and improvement after therapy, finding that for severe stutterers the adaptation rate might have some prognostic value but that consistency measures or terminal frequencies after adaptation had none.

Perhaps the most intriguing piece of research on prognosis was performed by Stromsta ${ }^{45}$ who examined the spectrograms of stuttering children who had been examined ten years earlier. He found that all those who showed normal changes in formant transitions and no breaks in air flow during moments of stuttering had recovered completely from stuttering whereas those who had shown abnormal formant transitions and airflow breaks were still stuttering. Two other interesting studies with implications for prognosis are those by Froeschels and Rieber ${ }^{13 a}$ who related auditory impercivity to severity, and by Ringel and Minifie ${ }^{37}$ who showed that severity was related to protensity (the ability to judge time).

What Attitudes or Covert Behaviours have Prognostic Value? Clinicians have often stressed the importance of motivation, anxiety, guilt attitudes, interpersonal relationships and other similar factors in determining prognosis. To review even a portion of the many statements in the literature bearing upon these would consume far too much space and therefore we confine ourselves primarily to the research findings. Andrews and Harris ${ }^{1}$ in their longitudinal study of British children who stuttered found no significant differences in test results or psychiatric interviews between them and their normal-speaking controls. Bullwinkle ${ }^{\mathrm{b}}$ treated 23 children who stuttered. Those who failed to progress satisfactorily were found to be more sensitive, shy, mother-attached and neurotic. Cooper ${ }^{9}$ reports that those stutterers with strong dependency needs seemed to make more progress in therapy than those who did not have them. Shames ${ }^{41}$ found a slight relationship between test scores indicating. "happy-goluckiness' and prognosis. Buscaglia ${ }^{7}$ suggests that the integration of the self concept should be considered as a factor in prognosis, a finding also 
mentioned by Clark and Murray ${ }^{8}$ Lanyon, ${ }^{28}$ using the MMPI found that Ego Strength was positively and Deviant and Repression responses were negatively correlated with improvement in therapy. Cooper ${ }^{9}$ showed that the stutterer's positive affective attitudes toward his clinician were related to progress. Sheehan ${ }^{43}$ failed to find any predictive value in Rorschach responses in terms of therapeutic outcome. In their investigation of recovered stutterers Sheehan and Martyn ${ }^{i 4}$ report that of 33 college stutterers who indicated that stuttering had become a part of the selfconcept only three had recovered, whereas of the $3 \mathrm{I}$ who had not so defined themselves, 29 had recovered. Zelan, Sheehan and Bugenthal, ${ }^{51}$ using the W-A-Y technique to investigate the self-concepts of 40 stutterers, found results indicating that success in therapy was dependent upon starting therapy with fewer negative self-percepts. Naylor and Rosenthal ${ }^{33}$ in a careful study of short term therapy with army stutterers failed to find any reliable or valid predictor of progress from either clinician's ratings or personality test data.

If this review of the research appears discouraging, we must point out that it probably reflects the state of behavioral science in general in the prediction of the outcome of treatment. The clinician for the time being must appraise the prognosis of his new patients without the objective tools he will have some day. Nevertheless, we are certain that experienced therapists do use the clues provided by the attitudes, emotionality, interpersonal relationships, self concepts and similar phenomena in making reasonably accurate judgments concerning the probable success of their treatment for a given individual.

Are there Developmental Factors Important in the Assessment of Prognosis? This question at least seems to yield some unanimity of reply. The younger the stutterer, the better the prognosis! We find this statement almost universally recognized. Wulffert ${ }^{50}$ in Bulgaria, Andrews and Harris ${ }^{1}$ in England, Dozukov ${ }^{13}$ in Czechoslovakia, Kamiyama ${ }^{25}$ in Japan, and Arnott $^{2}$ in Australia, are but a few of the many writers who agree in general with Glasner and Dahl ${ }^{19}$ in the United States who stated: The evidence today indicates that if the child's stuttering, as defined by the specialist, is not cleared up by the time the child enters school, his condition will more than likely become progressively worse. There is ample evidence, Milisen and Johnson, ${ }^{32}$ Pollitt, ${ }^{34}$ Bryngelson, ${ }^{5}$ Andrews and Harris, ${ }^{1}$ Shearer and Williams, ${ }^{42}$ Wingate, and Sheehan and Martyn, ${ }^{44}$ that a substantial proportion of children who begin to stutter seem to overcome it with or without professional help before adulthood. Generally, the opinion seems to be that the longer the stuttering has lasted, the worse the prognosis. Some controversy exists concerning the age of onset and prognosis. Dostalova ${ }^{12}$ and Wingate ${ }^{50}$ maintain that the later the onset of stuttering in children, the shorter the duration will be. Contrary findings have been reported by Jameson ${ }^{22}$ and others. Andrews and Harris ${ }^{1}$ found that four out of five stutterers who began to stutter overcame it before the age of ten years but that only one-fourth of those who were still stuttering at ten ever overcame it. 
Freund ${ }^{16}$ reviewed the literature on stuttering which began in adulthood and concludes that it is usually of short duration.

We have already described the effect of complexity and severity of stuttering as factors in prognosis. When these are viewed as developmental features of a disorder which usually begins with simple syllabic repetitions and progresses through a series of stages (Froeschels, ${ }^{18}$ Bloodstein, Van Riper $^{46}$ ) it is apparent that the exacerbation and growth of the disorder should be taken into account in determining the probable outcome.

Since this morbid development is usually oscillatory with frequent regressions into an earlier stage and often into periods of complete fluency, the therapist should always view this instability and reversal as favourable signs. Once the disorder becomes stabilized in an advanced stage, more difficulty in treatment can be expected.

We are certain that the prognosis for an individual stutterer is in large part determined by his basic evaluation of the disorder as a problem and by the positive or negative influences of the significant persons in his present environment and past history. Van $\operatorname{Riper}^{46}$ has attempted to formulate a tentative equation to include the impact of these factors but we need better models before they can be assessed with any real validity. Needless to say, one of the best means for determining a prognosis is the intensive study of the stutterer and his history, and some trial therapy itself.

In this discussion we have purposely avoided the quagmire of etiology and theory in which the nature of stuttering is presently buried. It seems reasonable to consider the disorder as a syndrome or collection of syndromes with differing components. We suspect that different types of stutterers have had different etiologies and that the differing final behaviours are the result of differential reinforcement. Does the cluttererstutterer have a better prognosis than the neurotic stutterer? This and other obvious questions of the same ilk cannot be answered at the present time. We can remember, however, that a favourable prognosis depends as much upon the competency of the therapist as it does upon the problem presented by the patient. Our successes or failures may help us assess this factor at least. A miserable thought, that!

\section{Summary}

This review of the literature on stuttering indicates that clues concerning prognosis can be obtained from the characteristics of the normal speech of stutterers, the overt stuttering behaviour itself, the attitudes, emotionality and interpersonal relationships, and from the developmental history. An appeal is made for more significant research.

\section{Opsomming}

Hierdie oorsig oor hakkelliteratuur dui daarop dat leidrade wat betref prognose verkry kan word van die eienskappe van normale spraak; die 
merkbare hakkelgedrag self, die houdings, emosionaliteit en interpersoonlike verhoudings, en die ontwikkelingsgeskiedenis van die hakkelaar. Daar word 'n pleidooi gelewer vir meer belanghebbende navorsing.

\section{REFERENCES}

I. Andrews, G. and Harris, H. (1964): The Syndrome of Stuttering. Spastics Socicty Medical Education and Information Unit, London.

2. Arnott, D. W. A. (1958): Stammering. Bulletin: Post Graduate Communications in Medicine, University of Sydney, Australia, 339-342.

3. Barbara, D. A. (editor) (1965): New Directions in Stuttering: Theory and Practice. C. C. Thomas, Springfield, Illinois, U.S.A.

4. Bloodstein, O. (1960): Development of Stuttering. J. Speech Hearing Disorders, 25, 219-237.

5. Bryngelson, B. (1938): Prognosis of Stuttering. J. Speech Disorders, 3, I 2 I-I 23.

6. Bullwinkle, B. A. (1933): Methods and Outcome of Treatment of Stutterers in a Child Guidance Clinic. Smith College Studies in Social Work, 4, 107-138.

7. Buscaglia, L. F. (I962): An Experimental Study of the Sarbin-Hardyck Test as an Index of Role Perception for Adolescent Stutterers. Ph.D. Thesis, University of Southern California.

8. Clark, R. M. and Murray, F. P. (1965): Alterations in Self Concept: A Barometer of Progress in Individuals Undergoing Therapy for Stuttering. Chapter 7 in Barbara, D. A. (ed.) New Directions in Stuttering, C. C. Thomas.

9. Cooper, E. B. (1966): Client-Clinician Relationships and Concomitant Factors in Stuttering Therapy. J. Speech Hearing Research, 9, 194-207.

Io. Danielson, H. (1963): Modern Psychotherapy Challenges Traditional Stuttering Therapy. (Swedish) Norsk Tidsskrift For Tale Og Stemme, 23, I I3-II7.

II. Diamond, M. (1953): An Investigation of Some Personality Differences Between Predominantly Tonic Stutterers and Predominantly Clonic Stutterers. Ph.D. Thesis, Syracuse University.

I2. Dostalova, N. and Dosuzkov, T. (1965): Aspects of Three Categories of Neurotic Stuttering. De Therapie et Loquellae. Proc. 13th Congress International Society Logopedics and Phoniatry, 1, 273-276.

13. Dosuzkov, B. (1960): On the Relationship Between Stuttering and Other Neuroses. (Czech), Ceskoskivenska Psychiatrie, 56, 395-402.

14. Douglass, E. and Quarrington, B. (I952): The Differentiation of the Interiorized and Exteriorized Secondary Stutterer. J. Speech Hearing Disorders, 17, $377-385$.

15. Freund, H. (1934): On Internal Stuttering (German) Zeitschrift Ges. Neurologie Psychiatrie, 151, 59I-598.

16. Freund, H. (1966): Psvchopathology and the Problems of Stuttering. C. C. Thomas, Springfield, Illinois, U.S.A.

17. Froeschels, E. (I933): Speech Therapy. Expression Co., Boston.

18. Froeschels, E. (1952): The Significance of Symptomatology for the Understanding of the Essence of Stuttering. Folia Phoniatrica, 4, $217-230$.

18a. Froeschels, E. and Ricber, R. W. (1963): The Problem of Auditory and Visual Imoercivity in Stutterers. Folia Phoniatrica, 15, 13-20.

19. Glasner, P. J. and Dahl, M. F. (I952): Stuttering-Prophylactic Program for Its Control. American J. Public Health, 42, IIII-III5.

20. Glasner, P. J. and Rosenthal, D. (I957): Parental Diagnosis of Stuttering in Young Children. J. Speech Hearing Disorders, 22, 288-295.

21. Hirschberg, J. (1964): Clinical Research: Stuttering (Hungarian), Orvoise Hetilap, 105, 780-784.

22. Jameson, A. (1955): Stammering in Children-Some Factors in the Diagnosis. Speech (London), 19, 60-67.

23. Johnson, W. (1959): The Onset of Stuttering. University Minnesota Press, Minneapolis.

24. Johnson, $\mathbb{W}$., Darley, $\mathrm{F}_{\text {. }}$ and Spriestersbach, $\mathrm{D}$. (1963): Diagnostic Methods in Speech Pathology. Harper and Row, New York.

25. Kamiyama, G. (I967) : A Handbook of Stuttering (Japanese) Kongo Shuppan, Tokyo.

Fournal of the South African Logopedic Society, Vol. 15, No. I: December 1968 
26. Kenyon, E. L. (I93I): Peripheral Physical Inhibition of Speech. An Essential Phenomenon and an Important Factor of Stammering. Oralism and Auralism, 10, I 5-3I.

27. Lanyon, R. (I965): Relationship of Adaptation and Consistency to Improvement in Stuttering Therapy. J. Speech Hearing Research, 8, 263-270.

28. Lanyon, R. (1966): The MMPI and Prognosis in Stuttering Therapy. J. Speech Hearing Disorders, 31, I86-I9I.

29. Luper, H. and Mulder, R. (1964): Stuttering Therapy for Children. PrenticcHall, Englewood Cliffs, N.J., U.S.A.

30. Luchsinger, R. and Dubois, C. (1963): Ein Vergleich der Sprachmelodie und Lautstärkekurve bei Normalen, Gehirnkranken und Stotteren. Folia Phoniatrica, 15, 28-4I.

31. Mahl, G. (I957): Disturbances and Silences in the Patient's Speech in Psychotherapy. J. Abnormal and Social Psychology, 42, 3-32.

32. Milisen, R. B. and Johnson, W. (1936): A Comparative Study of Stutterers, Former Stutterers and Normal Speakers Whose Handedness has been Changed. Archives of Speech, 1, 6I-86.

33. Naylor, R. V. and Rosenthal, W. S. (1968): Clinical Investigations of Stuttering : II. Treatment and Follow-Up of the Adult Stutterer. U.S. Army Medical Research and Development Command. Project No. 3A 02560 IA826 or 036. Bethesda, Maryland.

34. Pollitt, J. (I95I): A Review of Cases of Stammering. Speech (London), 15, 33-4I.

35. Quarrington, B. (1965): Stuttering as a Function of the Information Value, and Sentence Position of Words. J. Abnormal Psychology, 70, 22I-224.

36. Quarrington, B. and Douglass, E. (I960): Audibility Avoidance in Non-Vocalized Stutterers. J. Speech Hearing Disorders, 25, 258-265.

37. Ringel, R. and Minifie, F. (1966): Protensity Estimates of Stutterers and NonStutterers. J. Speech Hearing Research, 9, 289-296.

38. Robinson, F. (1964): Introduction to Stuttering. Prentice-Hall, Englewood Cliffs, N.J.

39. Schilling, A. and Goeler, D. von (I96I): On the Question of the Analysis of Monotony in Stutterers (German) Folia Phoniatrica, 13, 202-2I8.

40. Schonharl, E. (1964): Structural Changes in Stuttering due to Age. (German) H.N.O., 5, I52-I 54 .

41. Shames, G. (I953): An Investigation of Prognosis and Evaluation in Speech Therapy. J. Spcech Hearing Disorders, 17, 386-392.

42. Shearer, W. and Williams, J. D. (1965): Self Recovery from Stuttering. J. Spcech Hearing Disorders, 30. 288-290.

43. Sheehan, J. (I954): Rorschach Prognosis in Psychotherapy and Speech Therapy. I. Speech Hearing Disorders, 19, 288-290.

44. Sheehan, J. and Martyn, M. (1966): Spontaneous Recovery from Stuttering. J. Speech Hearing Research, 9, $121-135$.

45. 'Stromsta, C. (1965): A Spectographic Study of Dysfuencies Labeled as Stuttering by Parents. De Therapie et Loquellae. Proceedings 13th Congress International Society for Logopedics and Phoniatry, 1, 317-320.

46. Van Riper, C. (I963): Speech Correction: Principles and Methods. PrenticcHall, Englewood Cliffs, N.J., U.S.A.

47. Voelker, C. (1943): Post Therapy Observations on Over Two Thousand Cases with Speech Defects. Archives Otolaryngology, 38, 26I, 264.

48. Weiss, D. A. (I964) : Cluttering. Prentice-Hall, Englewood Cliffs, N.J., U.S.A.

49. Wendahl, R. and Cole, J. (I96I): Identification of Stuttering During Relatively Fluent Speech. J. Speech Hearing Research, 4, 28I-286.

5o. Wingate, M. E. (I964): Recovery from Stuttering. J. Speech Hcaring Disorders, 29, 312-321.

soa. Wulffert, M. F. (1964): Recent Work in Bulgaria on the Treatment of Logoneuroses (Russian). Review of Soviet Medical Sciences, 1, 57-61.

51. Zelan, S., Sheehan, J., and Bugenthal, J. (I954): Self Perceptions in Stuttering. J. Clinical Psychology, 10, 70-72.

52. Zerneri, L. (I965): Tentative d'Applicazione Delli Voci Retardata (DAF) Terapia Della Balbuzie Bolletino Della Societa Italiano Di Fonetica, Fonestria e Audiologia, 14, 125, 130. 